\title{
Simple Analyses on Reading of Women in Song Dynasty
}

\author{
Dongxia Song \\ Yancheng Teacher's University, History Department, Yancheng, 224000 China
}

\section{Keywords: Song Dynasty; Woman; Reading}

\begin{abstract}
Economy of Song Dynasty was relatively developed. The political environment was relatively stable, and literati could go to the official career by reading. Social reading atmosphere was good and a large number of outstanding writers emerged, promoting the rapid development of Chinese literature. Among these people, there are a group of very dazzling women, although they have not yet entered the school to learn, but had contacted reading through family education, and some excellent women had made good results in literature. The reading of female in the Song Dynasty is of great significance in the feudal society education system.
\end{abstract}

\section{Introduction}

Song Dynasty was a dynasty with great significance in the history of our country. Song Dynasty was weak in politics and diplomacy, but the society was thriving, economy and culture were greatly developed. Literary atmosphere is strong in Song Dynasty, from the emperor and officials to the ordinary people, there were a lot of people who were good at articles and literature. As Song Dynasty emphasized civil officials and neglected military, literati were widely respected, there were many people engaged in literary activities to enter the officer. In this context, women's reading situation in Song Dynasty had a qualitative leap than the predecessors, women read more common than Tang Dynasty. The reading was various and reading achievements were prominent. This paper will discuss from three aspects: social background, reading meaning and reading types of Song Dynasty women's reading. The reading situation of them will be made a comprehensive exposition.

\section{Social background of women's reading in Song Dynasty}

Political System. Song Dynasty is a centralized and highly developed feudal dynasty, and the society has a distinct sense of class, but in such a hierarchical society, the road of literati on the bottom has not been blocked. As the emphasis on civil officials and neglect of military and preferential treatment of literati and officialdom, the system engaging in politics of literati was improved and became a social boom. There were 3 channels to enter official: imperial examination, system selection and hereditary system.

Imperial Examination System was Adopted in Song Dynasty. The Ministry of Rites was responsible for the tributary examination (ie, imperial examination), setting up Jinshi and other subjects, including nine Confucianist classics, Five Classics, Kaiyuanli, Three History, Three Rites, Three Commentaries, Xuejiu, Mingjing, Mingfa and other subjects. The winners in Gong test "being ranked as No.1 and 2", after signed by the supervisor and monitor would be sent to the Ministry of Rites. After the exam in Ministry of Rites, there would be a test (that is, final imperial examination) in royal court. In order to prevent the capper, using relationship, Song Dynasty took a series of means to ensure fair examination: abolition of Tang Dynasty "recommended" system; covering the name of examinee, which is called "seal system"; transcribing the test paper for examiner reading over in case that the examiner knew the handwriting, which was known as the 
"transcripts system"; if the examiner had relationship with the imperial exam candidate, like relatives or teachers and students, which should be avoided; in the period of Song Taizong, if the children of high ranking officials won the tributary exam of Ministry of Rites, they still needed to accept the reexamination. Song Dynasty also implemented the "special approval" system. For the candidates who attended the imperial test for many times but still failed, they could also get approved by the emperor and went into the official, which greatly expanded the enrollment.

The system of Zhiju allows scholars to recommend themselves. The hereditary system had taken care of the children of high officials. These three systems complement each other and constitute the talent election system of Song Dynasty. In general, the Song Dynasty talent election system was fairer, and had more enrollment and less class restrictions, so it attracted a large number of talented people who had the ability to participate in the literacy. The society is also generally formed a craze of reading and imperial examination.

Family Education under Confucianism. In Song Dynasty, Neo-Confucianism formed with very large influence, and the status of Confucianism was further consolidated. People advocated "benevolence", "rites", restraint of desires, promoting strict social ethics. In Song Dynasty, the recognized moral norms and commendation include filial conduct, women virtues, righteousness and seclusion[1], in which women virtues is a very important part. In the family education, it is reflected in the education of women training. Female training is part of the family training. In the Song Dynasty, many scholars wrote family instructions to discipline their children, and women's instruction reflects the cultivation of women's morality, to a large extent contributed to the women's reading of Song Dynasty. In the Sima Guang's "Wen Gong Clan Regulations" (a total of ten volumes), the content about women training accounted for five volumes; in Yuan Cai's "Yuan Family Instructions", the "Close Relative" volume expressed the way to get along between husband and wife, sisters-in-law and nephews ;"Clan Regulations" Volume Eight Wife First Half pointed out: "for the wives, their virtues have six: the first called supple, the second called cleaning, the third called no jealous, the fourth called frugal, the fifth called respectful and cautious and the sixth called hardworking" [2]. There are a lot of books expressing such views, and they will not be shown one by one. In general, it is the moral requirements for women in Song Dynasty to abide by the three principles and five virtues, the three obediences and the four virtues, and the family view that men are superior to women. In this regard, the outstanding behavior can be commended by the court.

In addition to the women's instructions, in Song Dynasty, people's ideas on women's education have also changed. Sima Guang in the "Wen Gong Clan Regulations" Volume 6 also said: "all of people must learn, which the same is for men and women. So women, must read the "The Classic of Filial Piety", "The Analects of Confucius" and "Poetry" "Rites" at home, and slightly get the main idea. The female's work merely includes mulberry and sesame performance, making clothes, preparing food and drink. As for the superb skills of embroidery, orchestral instruments and poems, they are not suitable for women. So the talented women in the ancient time were eager to learn, including painting and history, all for self-control, from which we can see in the Song Dynasty, the idea that women are virtuous without talent has changed, and more and more literati began to pay attention to the education of women, and the individual phenomenon of sending female to private school to accept education directly emerged. In the "Female Filial Piety Painting", Cao Dajia sits on a high bed to face students for lecture, and women sit on the step ladder for listening. In the Song Dynasty, women can even teach. From Han Yuzhen "in childhood, YiAn householder taught poetry", Li Qingzhao had engaged in teaching work. This series of phenomena shows that although the phenomenon of male superiority was still dominant, Song Dynasty has paid more attention to 
women's education, which is especially rare in the feudal society education system[3].

Geisha Education In Goulan Culture. In the Song Dynasty, the literati indulged in dallying with prostitutes, and preferred those geisha who had literary talent, poetics, and been proficient in lute-playing, chess, calligraphy and painting, which contributed to the rapid development of professional education of geisha. Whether they were official prostitutes or private prostitutes, there was special training system for them. The royal court had Chamberlain for Ceremonials Rites and Music Department. The capital had east and west imperial music office. In the folk brothels and Goulan, there were a lot of geishas making a living as a performer. In the geisha vocational education, many geisha came into contact with books, widely read, and some geisha began to contact creation. They had made some contribution for the development of Song Poems. There were some famous prostitutes such as Li Shishi, Nie Shengqiong, Zhao Caiqing and so on.

In addition, the geishas in Song Dynasty were also generally in contact with the literati, who created excellent literary works for their own confidantes, and gave them to the geisha singing. All of the works of the poet Liu Yong in Northern Song Dynasty are almost related with his confidante. In the 340 poems of great writer Su Shi in "Ci-poem of Dong Po" (existing), there are 50 poems related with geishas. It can be said that the geisha contacting with the literati of various classes also promoted the women's reading in Song Dynasty.

The Printing Industry under Economic Development. The art of printing in Song Dynasty was widely used, and engraving printing had been very common. Typography made the book circulation costs be reduced greatly, directly promoting the great development of social education. Su Shi once said: "I still remember when I saw Mr.Laoru, he said when he was young, it's difficult to find 'Shih Chi' and 'Han Shu'. Even it's lucky enough to get them, he would copy them and read day and night for fear of loss. Recently, people simulated and carved the works of hundred school of thought, a large number of books can be printed each day"[3]. This shows that the reading habit of the people in Song dynasty had changed. The use of typography made people no longer be confined to the number of rare manuscripts, and many books could be bought on the market. The development of printing technology directly contributed to the circulation of books, coupled with the relatively stable economic environment of Song Dynasty, people lived more affluently. "Buying books" was much easier.

\section{The types of women 's reading in the Song Dynasty}

Classics of Buddhism and Taoism. In a study of 206 female epitaphs in Song Dynasty, the researchers said that the number of women who read the classic of Buddhist scriptures was 105, accounting for 51\%[4], which shows that in the Song Dynasty, Buddhism and Taoist thought were spread very widely, and these ideas actively entered into people's lives, and women did not need to learn orthodox Confucianism in order to enter the official, and became one of the audiences of Buddhism and Taoism. This provides another evidence that neo-confucianism in Song dynasty can appear by combining Confucianism, Buddhism and Taoism.

Confucian Classics. The survey shows that the 69 in 206 women in the Song dynasty read the Confucian classics, accounting for 33\%, ranked the second, which shows that the power of Confucianism was still strong, and occupying the mainstream in the Song Dynasty society. Moreover, the behavior that women read the Confucian classics was also likely to be affected by the impact of men at home. If the men in Song Dynasty wanted to enter into the official by imperial examination, Confucian classics were essential.

History Books. The survey shows that in the 206 Song Dynasty women, 33 read history books, accounting for $16.1 \%$, ranked the third. The reading of history books made the view of women 
more open. Chinese scholars advocate "history as a mirror", so history books occupy an important position in the book. In addition, the story and philosophy contained in history books was also very attractive for women.

Poetry Literature. The survey shows that in 206 Song Dynasty women, 30 read poetry literature books, accounting for $14.6 \%$, ranked the fourth. In the Song Dynasty, women reading poetry literature was not for the official, they did not have official pressure, so it's free to choose books. Poetry literature in the Song Dynasty represents popular culture more. The emergence of Song poems can prove that the literature was accepted by more and more people at the bottom. In view of this, Song Dynasty women read poetry literature more for pastime, but not utilitarian reading. Women could not only read the poetry literary for pastime, but also express emotions through writing. Song Dynasty poet Li Qingzhao is one of the best.

Feudalism Gentlewoman Classics. The survey shows that in the 206 Song Dynasty women, 21 read feudalism gentlewoman classics books, accounting for $10.2 \%$, ranked the fifth, which shows that the Song Dynasty attached great importance to the education of women's norms. Women also paid attention to their own words and deeds to make it ritual.

In addition to these, the Song Dynasty women also generally read music books, family instructions, novels of various philosophers, medicine, numeral art and other works, and the range was very wide. It can be seen the reading content of Song Dynasty women was very diverse. Their reading choice was independent and freer. According to the survey, the Song Dynasty women's reading generally lasted for life, and reading had become their normal life, and not just a moment of pastime.

\section{The Significance of Women 's Reading in Song Dynasty}

The women in Song Dynasty increased their social knowledge, got more comprehensive understanding of the world, broadened their field of vision and took initiative to use the views of the book to restrain themselves by reading[5].

Reading can broaden the perception of a person and change the reader's view of the world, thus affecting the reader's world outlook, outlook on life and values. Song Dynasty women were no exception, reading history books, classic works of various philosophers could make women no longer rigidly adhere to their own small circle of life, and their vision was more open. But at the same time, the women's moral standards advocated in Confucian classics and feudalism gentlewoman classics, they accepted without exception, and used this mainstream values to make their own words and deeds to regulate. In the Song dynasty, the mainstream values appreciated the loyal, filial, and feminine women, and also praised the outstanding women who were outstanding, favoring villagers, and loyal and patriotic. The normative role of the books on women's thoughts and behavior also appeared.

Song Dynasty Women could use Their Own Wisdom, Help Others to Learn, Live and Work Better Through Reading. This is reflected in the following aspects: Firstly, women could improve their self-cultivation through reading, thus affecting the education of the next generation. In the Song Dynasty, women still played the role of housewife in the family, so the education of the next generation was the focus of their lives. Reading could directly improve the women's self-cultivation, indirectly affected the education of children. Most of those who had achievements had received a good family education to grow up. Secondly, women understood the society through reading, to have their own ideas, and thus affected the work and doing things of men at home. In the families of officials, women's education is more common and rigorous than women's education in the ordinary families. They focused on the education of women and created a good family atmosphere. At the 
same time, talented women could help men in a certain extent. Although women could not really come forward to do their own official, but could become her husband's inner help, which was also an important way for women to play a role. Knowledgeable and intelligent women would also be respected and recognized by the family. Thirdly, women could become the object talking and describing with men through the exchange to help the expression of male emotions, which was more reflected in the geishas. The literati could seek comfort and pouring out, and the geishas could experience the charm of literature from the literati. The exchanges between two sides made a lot of wonderful works for the history of Chinese literature.

Song Dynasty Women Dedicated Their wwn Knowledge to the Society Through Reading, Leaving a Numberof Classic Works. "Whole Poetry of Song Dynasty" contains the works of more than 90 female poets, a total of more than 300 articles. It also contains more than 200 poetess' works. The female authors of "The Complete Works of Song Dynasty" are more than 20[6]. These data show the big achievement due to widely reading of Song Dynasty. A lot of excellent female writers were created, and they were educated and reasonable, had delicate mind, and the style that men did not have. Their works are very bright. Song poem itself began from the popular culture, so it had wide public audience, high degree of acceptance, and could compose music, thus it was liked by a lot of people including women. Women reading became one part of the public reading, naturally made its own contribution for the promotion and popularity of Song Poem.

Among many female writers, the poet Li Qingzhao was the best one with the highest achievement. Li Qingzhao was born in a literary family. Her father Li Gefei had very abundant collection of books, and her mother Wang Shi also could read and write. Under such a family atmosphere, Li Qingzhao had read a large number of books since childhood. She had exceptional literary style, and her poems had elegant style, simple nature, sophisticated idea and full emotion, and were relished by the later generations.

\section{Conclusion}

In summary, women's reading in Song Dynasty is more popular in the public level than the previous generation, but the strict moral norms on women of neo-Confucianism in Song Dynasty bound the liberation of female thought. Alough, the Song Dynasty women's reading was relatively free, but always caught in the framework of feudal society. The female reading in the Song Dynasty society was helpful to the stability of society and improvement of individual's quality, and had made an indelible contribution to the prosperity of Song Dynasty poetry and literature.

\section{References}

[1] Gu Hongfen. Between Rise and Fall: Study on the Social Evaluation of the Women in Song Dynasty [D]. Sichuan Normal University, 2012.

[2] Gou Xiao. On the Issue of Female Education in the Song Dynasty [J]. Border Economy and Culture, 2016, (02): 63-64.

[3] Xie Jiangshan. Female Images and Their Lives in Song Dynasty [D]. Shanghai Normal University, 2015.

[4] Tie Aihua. Women's Reading in the Song Dynasty Society - the Study of Epitaph [J] .Jingyang, 2005, (05): 75-78.

[5] Han Dongdong. Discussion on Female Marriage and Family Status in Song Dynasty [D]. Anhui University, 2010. 
[6] Tie Aihua. First Discussion on Song Dynasty Female Reading Activities [J]. Journal of History, 2005, (10): 36-41. 